\title{
How to increase the efficiency of bond covenants: a proposal for the Italian corporate market
}

\author{
Flavio Bazzana $\cdot$ Marco Palmieri
}

Published online: 15 December 2010

(C) Springer Science+Business Media, LLC 2010

\begin{abstract}
Covenants are particular clauses in the debt contracts of firms that restrict business policy, giving creditors the possibility of putting precise actions into force (normally early repayment) when the covenants are violated. The main purpose of covenants given in the literature is to resolve the conflicts of interest between shareholders and bondholders. Lack of coordination between bondholders may, however, reduce the efficiency of these instruments. We propose an application of the Italian law allowing the insertion of a mandatory representation into the new financial hybrid contracts to give an investment firm the right to act with full power on behalf of the bondholders. We show the impact of this proposal using a formalised example for the issuance of a bond with a covenant for a firm.
\end{abstract}

Keywords Bond covenants · Bondholder's trustee

JEL Classification $\mathrm{G} 12 \cdot \mathrm{K} 22 \cdot \mathrm{G} 32$

\section{Introduction}

Covenants are particular clauses in the debt contracts of firms that restrict business policy, giving creditors the possibility of putting precise actions into force (normally

Sections 2.1 and 3 are attributable to Flavio Bazzana and Sects. 2.2 and 4, to Marco Palmieri. Sections 1, 5, and 6 were written jointly.

\section{F. Bazzana $(\bowtie)$}

Faculty of Economics, University of Trento, Trento, Italy

e-mail: flavio.bazzana@unitn.it

\section{Palmieri}

Faculty of Law, University of Bologna, Bologna, Italy

e-mail: m.palmieri@unibo.it 
early repayment) when the covenants are violated. The main reason for the existence of bond covenants is to solve the conflicts of interest between shareholders and bondholders. In fact, shareholders and bondholders, both of whom have different rights to the cash flows generated by the firm, often suffer because of conflict-of-interest situations. The shareholders can make business policies that reduce the debt market value, resulting in a transfer of wealth from the bondholders. In addition, the choice of risky investments gives rise to conflict between the two types of investors because the additional risk will be distributed in an asymmetric way that does not favour bondholders. Covenants limiting such behaviour, therefore, can reduce the conflicts of interest between the two parties. Conversely, covenants produce undesirable effects, thus reducing flexibility in business policy. The type of covenant and its limits must therefore be chosen in such a way as to avoid compromising business policy and to show credibility to the bondholders by reducing conflicts of interests.

The role of covenants and the conflicts between shareholders and debt holders have been classified in an organic way by Smith and Warner (1979). Under certain assumptions about the firm's structure, the most important of which is the lack of agency costs in all other types of contracts, the two authors identified three main sources of conflict: (1) dividend payments (2) claim dilution, and (3) assets substitution. A fourth cause, identified by Myers (1977), deals with underinvestment. The presence of these conflicts influences bond issuing, as the price of the bond embodies the firm's policies. In fact, the debt issued by a company has a financial component and a structural component. The first component is subject to financial risk because the price of debt changes according to variations in the interest rate. The second component is subject to business risk, which is estimated according to the variability of the asset value. The cash flows to the debt holders usually do not depend on the second component, and thus any change in the business risk associated with the bond issue entails a corresponding change in market price. In addition, conflict of interest also arises from different rights to the cash flows. Shareholders receive the residual cash flow after paying the bondholders, who are entitled to fixed cash flows. The limited liability of the shareholders to the net capital, together with bankruptcy costs, can also change the risk preferences of shareholders and debt holders (see Damodaran 2001).

The conflicts of interest between shareholders and bondholders can be reduced by including appropriate covenants in debt contracts to influence a firm's policies and to reduce the transfer of wealth to shareholders. However, the use of covenants involves certain costs, both for the firm that includes these limiting clauses in the debt contracts and for the debt holders who subscribe to a debt covenant instrument. Covenants are costly for the firm because they restrict future financing and investment decisions. Firms with high growth opportunities prefer to have few restrictive covenants because they must preserve future financing and investment flexibility. Conversely, restrictive covenants may be more bearable for firms with low growth opportunities (Beatty et al. 2002; Billet et al. 2007). At the same time, restrictions on flexibility are compensated by the lower interest rate that the firm pays to the bondholders compared to an equivalent bond without covenants (Smith and Warner 1979). A second type of cost consists of violation costs. In fact, if the 
company violates the covenant, the creditor may normally require early repayment or its renegotiation. In both cases, the company and the creditors must bear a number of costs, i.e., renegotiation, refinancing, and restructuring costs (Beneish and Press 1993), that can reduce the efficiency of covenants.

In the last few years, two important study areas have been examined in detail: (i) problems relating to the violation of covenants and (ii) the differences between covenants for public debt and those for private debt. Regarding the former area, most of the literature addresses various aspects of accounting (Beatty et al. 2002; Beatty and Weber 2003); a few articles consider the renegotiation of the debt contract after covenant violations (Chava and Roberts 2008; Garleanu and Zwiebel 2009). The main focus of the articles related to the study of covenants for public debt and those for private debt is the differences within bond covenants in typical banking topics, such as banking relationships (Mather and Peirson 2006; Demiroglu and James 2010), the role of collaterals, and monitoring (Black et al. 2004; Carletti 2004).

In our paper, we propose an innovative application of the Italian law to increase the coordination level between bondholders, using a formalised example to show its impact on covenant violation costs. Regarding the legal aspects, this proposal has yet to be discussed in Italian legal literature. There are a few analyses of the new securities introduced in the Italian corporate financial market (Corsi 2003; Dimundo 2003; Ferri 2003; Lamandini 2003; Notari 2003; Pisani Massamormile 2003; Perugino 2004; Cian 2005; Lolli 2005; Enriques 2005b; Tombari 2006; Notari and Giannelli 2008), which we will use in our proposal, but no investigations have been made regarding their possible application to increase the covenant's efficiency. As far as we know, our paper is the first to present a contractual model of a full-power delegation of the bondholders as an alternative to the representative model provided by the Italian Civil Code. ${ }^{1}$

Regarding the formalised example, we refer to the agency theory of covenants (ATC), first postulated by Jensen and Meckling (1976) and extended by Myers (1977) and Smith and Warner (1979). This theory assumes that as long as the offsetting benefits exceed the costs of the constraints imposed by the covenants, the lender will include covenants in debt contracts. According to Smith and Warner (1979), the benefit consists of a reduction in agency costs, which translates into lower financing costs. Coherent with this theory, our example is based on the assumption that the inclusion of an optimal set of financial covenants in the debt contract is the result of a revenues-costs trade-off, both for the lender and for the borrower. In accord with the pricing models of Bradley and Roberts (2004) and Gârleanu and Zwiebel (2009), our example stems from a costs-benefits trade-off approach. In defining the costs and benefits of the covenant inclusion, we formally introduce additional elements, such as the probability of covenant violation, the

\footnotetext{
${ }^{1}$ Until the first years of the present decade, Italian companies recurred to the "Euro bond market" to finance their activities. Normally, the securities were emitted by a Dutch or a Luxembourger company, and the bondholders were represented by an English trustee (Onado 2003; Di Staso 2004; Fimmanò 2004; Fortunato 2004; Pardolesi and Portolano 2004; Inzitari 2005). The use of this foreign legal scheme and the consequent bondholders' deficiency of perceiving the worsened financial position of the lenders can be considered one of the main reasons for the Parmalat and Cirio cases (Abriani 2004; Nigro 2005).
} 
specification of the different costs that may arise should the covenant violation occur and the costs existing during the whole period of the covenant. Regarding this last aspect, we refer to the analysis of Beneish and Press (1993) in which the authors classify three types of violation costs. In particular, we formalise the renegotiation costs that the lender must pay in such a case, and we identify the effect of the degree of coordination on the renegotiation costs between bondholders and, ultimately, on the efficiency of the use of covenants. Lack of coordination between debt holders may in fact reduce the efficiency due to the high amount of expected renegotiation costs following the covenant violation.

These results have led some authors to search for possible solutions to increase the efficiency of bond covenants in which the bondholders have a low level of coordination. The first paper with an effective operative proposal was by Amihud et al. (2000), who emphasised that the choice between private debt and public debt, both with covenants, is in fact a trade-off for the enterprise. Bond issues are more liquid and easily diversifiable by the investors than bank financing. In contrast, bond covenants are weaker and the agency costs higher when compared to the best possibility of renegotiation and monitoring of bank financing. The limited protection of the bondholders involves a higher spread in bond issue than in bank financing. The authors propose the creation of a "supertrustee" acting on behalf of the bondholders to "emulate the advantages of private loans-active monitoring, tight covenants and ease of recontracting-while retaining the benefits of liquidity and ease of diversification" (Amihud et al. 2000, p. 116). Recently, Bratton (2006) proposed an amendment to the U.S. legislation on bondholder trustees to increase the power of action during the renegotiation. Commenting on the work of Bratton (2006), Schmidt (2006) proposes to reduce the quorum for decisions by the assembly to avoid delays in the process of renegotiation. He goes even further, identifying the amendment in the debt contract as a radical solution to the problem. The bondholders could, in fact, be granted certain rights in business choices when a specific covenant is violated.

Our work proceeds as follows. First, we will describe, according to the relevant literature, the empirical evidence on the costs of covenant violation, discussing the empirical studies and the most important Italian case studies. Then, using a formalised example, both for the firm and the bondholders, we will identify the cost of a bond issue and its relationship to the level of coordination of the bondholders. In the third section, we will analyse the new kind of debt notes introduced by the recent reform of Italian corporate law. We will then propose a possible way to use these financial instruments to provide a form of representation of creditors to increase their coordination level. We end our work with our conclusions.

\section{Empirical evidence}

The bondholders' coordination level and the violation costs in the case of technical default play an important role in the efficiency of the covenants to reduce the conflict of interest between bondholders and shareholders. Comparing the different empirical studies on covenants, it is possible to show that with a higher level of 
coordination, the expected violation costs will be lower compared to situations in which the bondholders are less able to coordinate. Similar results can be shown in the most important Italian case studies.

\subsection{Empirical studies}

Many empirical studies of covenants have tried to test the debt covenant hypothesis proposed by Smith and Warner (1979), i.e., that firms choose accounting methods to maximise the slack in debt covenant constraints (Niskanen and Niskanen 2004; Asquith et al. 2005; Paglia and Mullineaux 2006). In particular, Smith (1993) and Sweeney (1994) noticed a different attitude toward covenant violations among banks and bondholders. Private debt covenants are usually set more tightly than are public debt covenants. This results in a greater likelihood of covenant violations in private debt, as opposed to public debt. Both authors hypothesise that this difference is mainly due to the different degree of coordination between the two classes of creditors. Indeed, in the case of private debt, the creditors are limited and consist mainly of banks. In the case of public debt, the number of creditors is significantly higher, and the creditors are made up mainly of non-institutional investors, resulting in greater difficulty in reaching an agreement in cases of violation. This implies a higher total violation cost. Thus, although covenants are effective in reducing the conflicts of interest between shareholders and bondholders, the efficiency of the instrument is reduced in the case of public debt due to coordination problems. The issue of coordination among creditors has also been addressed by Rajan (1992), who asserted that if a firm borrows from multiple creditors, it can limit the monopoly power typical of a single creditor. However, Bolton and Scharfstein (1996), discussing the optimal number of creditors, explain that if a company raises funds from different creditors, a potential renegotiation between the creditors and the firm may become more difficult. The study of Hubert and Schäfer (2002) brought to light a trade-off: if the advantages of eliminating the monopoly power of a single creditor are higher than the drawbacks of increasing the risks of failure due to creditors' coordination problems, it is worthwhile for a firm to raise funds from different creditors. Indeed, the authors derived this condition from the fact that an increased number of lenders means that the total costs of becoming informed and monitoring the firm become prohibitive. Other studies have emphasised the role of coordination in organizations. Camerer and Knez (1996) highlighted the importance of convergent expectations, modelling the problem with a prisoner's dilemma game, whereas Bris and Welch (2005) found that when the quality of the borrower is not known, it is better to choose the most concentrated creditors. An empirical study by Ongena and Smith (2000) stated that working with multiple creditors will be beneficial in countries where bankruptcy costs are low or firms are protected by particular bankruptcy regulations. Some studies have further explored creditor coordination problems; Detragiache et al. (2000) asserted that multiple banking is costly because it involves greater transaction costs, such as screening and monitoring costs, and that the renegotiation of the debt is likely to be more complex due to the many creditors involved. Therefore, to outweigh these costs, multiple banking borrowings have to offer enough benefits, such as the opportunity 
for banks to diversify the firm-specific credit risk. Morris and Shin (2004) investigated how coordination problems among creditors may affect the price of debt. Takeda (2003) extended a previous version of this model, analyzing the role of large creditors in the coordination of creditors. In a subsequent research paper, Takeda and Takeda (2008) considered the influence of creditor coordination problems on corporate bond prices and discussed the role of large creditors in Japan. Their results suggested that corporate bond prices may be affected by large creditors, such as the main banks, through their influence on creditor coordination.

Some empirical works have documented the differences between covenants by comparing public and private debt contracts in terms of the number, variety, and restrictiveness of covenants. In particular, Cotter (1998) studied covenants included in the private debt contracts of Australian firms. It appears that the restrictiveness of covenants is correlated with the firm size and the industry, but others features may still be explored, such as the firm's credit rating or the term of the loan. Further research on private debt highlights a negative relationship between firm size and the existence of a covenant (Niskanen and Niskanen 2004). Regarding covenants on public debt, some studies show a positive relationship between a firm's growth opportunities and the inclusion of covenants (Bradley and Roberts 2004), while others outline a negative relationship (Nash et al. 2003). Mather (1999) and Mather and Peirson (2006) also survey both private and public debt contracts; they find that private contracts contain more restrictive covenants and are more flexible in terms of renegotiation. Also, the recent study by Kwan and Carleton (2010) provides evidence that private placement contracts are more likely to have restrictive covenants than public bonds.

\subsection{Italian case studies}

Although the annual savings of Italian households amounted to about 49 billion and 690 million $€$ in 2009 (Report of the Governor of the Bank of Italy, 31 May 2010), only an infinitesimal fraction of these sums directly financed Italian firms. The Italian financial market is indeed still characterised by a scarce use of bonds by companies. Currently, the only corporate bonds issued in the domestic market belong to a few state-controlled companies operating in the energy sector (i.e., ENI SPA and ENEL SPA). For this reason, the adoption of covenants is currently limited in the Italian bond market, while their use is common in the structuring of syndicated loans (in the form of so-called loan covenants, i.e., Unicredit Banca Mediocredito and Centrale dei Bilanci 2005).

The main reasons for this peculiarity of the Italian financial market are the small size of most companies (Vella 2002; Canovi et al. 2007) and the subsequent development of a close relationship that ties these companies with banks as primary sources of funding (Bertinetti 2000; Corigliano 2007).

Additional factors that prevent a more extensive use of corporate bonds include the costs of organising the public offerings of securities (Banfi and Di Pasquale 2003; Pagnoni 2005) and the lack of financial literacy among money savers, which induces them to prefer more traditional "safe harbour" investments, such as emissions of sovereign debt (only one Italian family in 25 invests in non-financial 
corporate bonds, see Report for 2007 of Consob, Rome, March 31, 2008, p. 174 ff.). For these reasons and to gain tax advantages (Eidenmüller et al. 2010), the few major Italian companies that need to finance their activities with bond debt prefer to skip the domestic market and turn to the so-called international "Eurobond" market. Normally, these securities are publicly issued or, more often, privately placed under English law by the Italian company or a Dutch or Luxemburger subsidiary guaranteed by the Italian parent. They are traded on the Luxembourg Stock Exchange or on the "over the counter" market, and the bondholders are represented by a trustee (Onado 2003; Di Staso 2004; Fimmanò 2004; Fortunato 2004; Pardolesi and Portolano 2004; Inzitari 2005). In this market, the use of covenants is quite frequent.

Until the first years of the last decade, several small- and medium-capitalised SPAs were financed with issues of "Eurobonds". Although they were privately placed on the international markets, these securities were principally held by Italian money savers partly because the modest amounts of these speculative grade-rated securities made them deeply illiquid and, therefore, unattractive for professional investors (Stanca 2003; Banfi and Di Pasquale 2003; Zara and Feltrinelli 2006). The issuers were repaid the considerable costs of these financial operations principally because the adoption of this foreign legal scheme allowed them to bypass the emission limits provided by the Italian law before the Company Law Reform of 2003 was put into effect.

This form of indirect public placement can be considered the main reason for the aggravation of the financial crises that have involved the smaller issuers as well as the genesis of the best-known bankruptcies of Cirio SPA in November 2002 and Parmalat SPA in December 2003. The lack of a mandatory prospectus and the inability of Italian bondholders to perceive the worsened financial position of debtors and their guarantors had made possible an uncontrolled over-indebtedness of the corporate groups (Abriani 2004; Nigro 2005), often with the support of the lending banks in a conflict of interest.

The numerous financial difficulties that many issuers of Eurobonds have encountered have hobbled investor confidence in this important part of the market, leaving the banks in charge to finance the small or medium capitalisation companies.

The study of the few cases of positive renegotiated debt issued by the foreign subsidiaries of Italian corporate groups is useful to understand the weaknesses of international practices in renegotiating the terms of debt in cases of default and, indirectly, the behaviour of the average Italian money saver. The investigation of the amendments to the "Eurobond" issues of Frati SPA, Fantuzzi SPA and Italtractor SPA shows how (i) the difficulty of coordination of Italian dispersed retail investors (ii) the risk of opportunistic behaviours by some professional creditors and (iii) the time needed to obtain the consent of the majority in the proposal for reformulating the terms of the debt can still pose a serious risk to the success of the operation even if the bondholders are protected by a foreign trustee.

The first problem is evident in the analysis of the Frati case; the termination of the covenants on the loan guarantee offered by two subsidiaries of the corporate group as negotiated by the trustee (a necessary step to transfer the payment of interests and to recover the funds necessary to pay the debt) was approved by the 
bondholders only in a second meeting, where the quorum required by the trust deed was only $25 \%$ of the loan capital.

The renegotiation of the debt of the Fantuzzi Group looks very similar; in spite of the first restructuring in 2004 (which had obtained more than three quarters consent of the investors in the first meeting), the subsequent rescheduling of bonds in August of 2008 (more than 1 month from the due date for repayment) required a second meeting to gain approval.

The analysis of the vote in this bondholders' assembly highlights the risk of possible opportunistic behaviour by creditors; in the second meeting, the will of Italian small investors prevailed by a few votes on the negative motion proposed by a hedge fund and an Italian bank that bet on the default of the issuer.

The impact of the time factor is in full evidence in the case of Italtractor; the debt was rescheduled just over 6 months after the default caused by technical failure to pay the coupon, partly due to the publication of a prospectus as required by Consob for giving the authorization to the public exchange offer.

Although these three examples all concluded with a successful renegotiation of the debt, they show the difficulties of applying the foreign contractual model to the context of the Italian capital market, especially where non-professional investors are involved. The power of a trustee to renegotiate the terms of the loan on behalf of Italian bondholders in the event of a default of a covenant appears to be too weak because of its exposure to the approval of the creditors, who are often not sufficiently informed, prepared or economically motivated to participate in debt renegotiation.

Moreover, as demonstrated by the Parmalat case, all of the residual powers of the trustee are intended to cease when the debtor becomes insolvent, as the Italian law (Legislative Decree No 270/1999 and subsequent amendments) provides that the definition of claims should be entrusted to a commissioner appointed by the government in cases of financial crisis in large enterprises (this concentration of power in the hands of a commissioner has made possible, for example, the transformation of the unpaid bonds into shares of the restructured company, thus giving rise to the largest datio in solutum, i.e., payment in kind, in Italian economic history; Inzitari 2005).

From the framework outlined here, a more effective use of covenants can be seen as a possible solution to revive the Italian corporate bonds market, to restore investor confidence and to break down the financing costs of firms (Bradley and Roberts 2004; Chava et al. 2005). To become an effective catalyst for the development of a real alternative source of financing to credit institutions (Cafaggi 2002; Qi and Wald 2008), however, the adoption of covenants should be associated with a kind of rational conduct that only a single creditor, i.e., a bank, can exercise. A similar scenario would reduce the cost of the debt rescheduling through a considerable saving of time and reduced risk of opportunistic behaviours in the event of default, allowing the creation of a longer-term financing relationship. Although Italian law does not provide that the bondholders are represented by a trustee, the corporate law reform of 2003 seems to have indirectly allowed similar forms of representation, giving them full powers in the same way as suggested by Amihud et al. (2000) for their "supertrustee". 


\section{A formalised example}

To analyse the roles of the coordination level among bondholders and the violation costs in the case of technical default in explaining the efficiency of covenants, we will use a simple formalised example. We build two revenue-cost functions, one for the firm and a separate one for the bondholders. In the first case, the firm is subject to two types of costs, i.e., the loss of flexibility in business policy and the expected cost of covenant violations, and one type of revenue, i.e., the lower interest rate as compared to an equivalent bond without covenants. Suppose that a firm should issue a bond with nominal value $D$ and must choose between a standard contract with spread $s$ and a contract with a financial covenant with a reduction $b$ on the spread. We define $d$, the relative distance between the current value of the financial ratio of the firm and the "threshold" value of the ratio, as set by the covenant and the probability of covenant violation $p_{F}$ as estimated by the firm. Let $F$ be the costs arising from the loss of flexibility in corporate policy, and let $C_{F}$ be the total violation costs, which account for both the restructuring and the refinancing costs. Both types of costs are expressed in monetary value. For simplicity, let us assume risk neutrality of the firm, so we can only take into account the expected values of the problem. The firm will choose the issue with covenants only if

$$
D \times s \geq D \times(s-b)+F(d)+p_{F}(d) \times C_{F} .
$$

If we divide both terms by the face value of the bond $(D)$, we get

$$
b \geq f(d)+p_{F}(d) \times c_{F},
$$

in which $f(d)=F(d) / D$ and $c_{F}=C_{F} / D$. We assume that the costs of flexibility loss and the probability of violation decrease in respect to $d$, i.e.,

$$
\frac{\partial f(d)}{\partial d} \leq 0, \frac{\partial p_{F}(d)}{\partial d} \leq 0 .
$$

It is reasonable to assume that the cost resulting from the loss of flexibility is a decreasing function with respect to the strength of the covenants. Consider, for example, a company that should finance a new investment but is subject to covenants on financial leverage. The average cost of capital required will be higher when the value of the financial leverage is closer to the value defined by the covenant. The company, in fact, will seek to use equity instead of debt, so as not to violate the covenants, but this leads to an average cost of funding that is higher than that in the absence of covenants. Also, with regard to the probability of violation, it seems reasonable to assume a decreasing function with respect to the strength of the covenant. Indeed, the closer the financial ratio is to the threshold value, the more likely it becomes that the company violates the covenant. This can happen intentionally, if the business policy is too limited by the covenant, regardless of whether or not the situation arises as a result of unexpected changes in the components of the financial statement. Consider, as an example, a covenant on the return on sales (ROS). If the covenant is stringent, it is more likely that the variability of sales would result in a violation of the covenant. 
Following Eq. 2, the choice set for the firm is expressed in the following:

$$
\Omega_{F}=\left\{(b, d) \mid b-f(d)-p_{F}(d) \times c_{F} \geq 0\right\} .
$$

As defined by the expression (4), the firm decides to issue a bond covenant only if the combination of the spread reduction $(b)$ and the distance to the covenant threshold $(d)$ are such that the benefits of the financing are higher than the total costs. Given that both the costs and the revenues (the spread reduction) are negatively related to $d$, the firm has to balance a trade-off. The firm's objective function to maximise is therefore expressed in the above Eq. 4, subject to the bondholders' constraints, as described in the succeeding paragraph.

If we look on the bondholders' side, they are subject to the reduction of the spread $b$, the renegotiation costs $C_{B}$ in the event of the violation of the covenant (with probability $p_{B}$, as estimated by the bondholders), and the monitoring of the firm $M_{B}$. At the same time, the bondholders benefit from revenues in case of early repayment $R_{B}$; these revenues consist of the difference between the nominal and the market values. This difference accounts for the fact that when the firm violates the covenant, the market price of the bond will be lower, thus reflecting the implicit greater risk.

The asymmetric information between borrower and lender is reflected in their different estimations of the probability of covenant violation. As a matter of fact, the firm estimates $p_{F}$, which differs from the bondholders' calculation of $p_{B}$. We assume that the firm is able to work out the bondholders' estimated probability due some information disclosure in the market, such as the organisation of investor roadshows or the decision to publish a solicited rating on specific investment projects or on the firm in general. This disclosure allows the bondholders to complete their partial information and the firm to control and build up the information flow. This assumption mitigates the asymmetric information issue, thus amplifying the covenant's efficiency.

Now, we introduce into the formal example the role of coordination among bondholders as an ad hoc assumption. We assume that the total violation costs of the covenant and the costs of monitoring are functions of the coordination level co, which ranges from 0 , in the case of maximum coordination, to 1 , in the case of minimum coordination. To measure the coordination level of bondholders, we can refer to some recent theoretical research (Hubert and Schäfer 2002; Morris and Shin 2004; Takeda and Takeda 2008). Therefore, the bondholders will underwrite the bond issue only if

$$
D \times s \leq D \times(s-b)-p_{B}(d) \times C_{B}(c o)-M_{B}(c o)+p_{B}(d) \times R_{B}(d) .
$$

If we divide both terms by the face value of the bond $(D)$, the expression $(5)$ can be simplified as follows:

$$
b \leq p_{B}(d) \times\left[r_{B}(d)-c_{B}(c o)\right]-m_{B}(c o),
$$

in which $r_{B}(d)=R_{B}(d) / D, c_{B}(c o)=C_{B}(c o) / D$ and $m_{B}(c o)=M_{B}(c o) / D$. As in the previous case and for the same reasons, the probability of violation, as estimated by the bondholders, decreases with respect to $d$, while the revenues from the early repayment are supposedly growing. Indeed, a greater distance $d$ set at the time of the issue results in a greater reduction in market price in the event of violation. We 
implicitly suppose that the risk for the firm will increase proportionally with the decrease in the value of $d$. Following these considerations, the signs of the derivatives are as follows:

$$
\frac{\partial p_{B}(d)}{\partial d} \leq 0, \frac{\partial r_{B}(d)}{\partial d} \geq 0 .
$$

Moreover, both the violation and the monitoring costs increase with respect to $c o$. For the violation costs, if we assume that bondholders are not very coordinated, for example, when represented by a large number of consumers, it will be difficult to reach a rapid decision on the restructuring of debt. In addition, the costs in the management of bondholders meetings are likely to be high. The situation is different if the bondholders are small in number or if they are represented by a trustee. In this case, a reduction in the decision times and a reduction in the costs in the management of meetings are likely. Regarding the monitoring costs, with a higher number of bondholders, the single cost of monitoring will be duplicated for the total number of bondholders, resulting in a higher total cost. In the case of a trustee, or when the bondholders are few, the total cost of monitoring will necessarily be lower. Thus, the signs of the derivatives are as follows:

$$
\frac{\partial c_{B}(c o)}{\partial c o} \geq 0, \frac{\partial m_{B}(c o)}{\partial c o} \geq 0 .
$$

The choice set for the bondholders thus becomes

$$
\Omega_{B}=\left\{(b, d) \mid b-p_{B}(d)\left[r_{B}(d)-c_{B}(c o)\right]+m_{B}(c o) \leq 0\right\} .
$$

As defined by the expression (9), the bondholders agree to subscribe to a bond with a covenant only if the combination of the spread reduction $(b)$ and the distance to the covenant threshold $(d)$ are such that the total costs (the lower interest, monitoring, and renegotiating costs) are lower than the expected revenues associated with the reduction in market price in the event of a covenant violation.

The firm has to maximise the expected revenues, the total costs of which are dependent on $d$, subject to the bondholders' function constraints:

$$
\max _{(b, d) \in \Omega_{F}} b-f(d)-p_{F}(d) \times c_{F} \text { s.t. }(b, d) \in \Omega_{B} .
$$

The first-order conditions for an internal solution are as follows:

$$
\underbrace{\frac{\partial p_{B}(d)}{\partial d}}_{\leq 0}\left[r_{B}(d)-c_{B}(c o)\right]+\underbrace{p_{B}(d) \frac{\partial r_{B}(d)}{\partial d}}_{\geq 0} \underbrace{-\frac{\partial f(d)}{\partial d}-\frac{\partial p_{F}(d)}{\partial d} c_{F}}_{\geq 0}=0 .
$$

Given the signs of the derivatives, the necessary condition ${ }^{2}$ for the existence of a solution to expression (11) is that the costs of renegotiation should be lower than the revenues from early repayment in the event of a covenant violation, which is expressed as follows:

\footnotetext{
${ }^{2}$ The sufficient conditions for an internal solution for the maximisation problem are qualitatively similar, with respect to the discussion on the coordination level, to the necessary conditions.
} 


$$
r_{B}(d)-c_{B}(c o) \geq 0 .
$$

Given the benefits arising from the prepayment in case of covenant violation, which depend on the settled parameter $d$, Eq. 12 holds as long as the level of coordination among the debt holders guarantees that any eventual renegotiation costs would be lower than the expected benefits. Conversely, given a specific level of debt holders' coordination, the Eq. 12 holds if the covenant is set at a threshold sufficient to ensure that the consequent benefits offset the corresponding costs. As expressed in (8), a low level of coordination between the bondholders increases renegotiation costs (parameter $c o$ increases). Other things being equal, the bond will be issued with a higher value of $d$. If the coordination level is extremely low, the firm could consider it more convenient to issue a standard bond. In the latter case, both the firm and the bondholders face an inefficient condition with respect to the issue of a covenant bond. In fact, by issuing standard bonds the firm bears a higher cost of borrowing, whereas the bondholders do not benefit from the mitigation of the agency problems. Moreover, a situation could occur where the bondholders are not at all willing to underwrite such bonds, although they would be more remunerative, given the high associated expected agency costs. Therefore, only a high level of coordination, such as would be the case if the bondholders decided to rely on a trustee, would lead to a reduction in the expected renegotiation costs in the event of a covenant violation and would consequently make the choice of issuing bonds with a covenant an efficient one.

\section{The new securities introduced in the Italian corporate financial market}

The 2003 corporate law reform brought considerable changes to the Italian Civil Code of 1942 by overcoming the historic limitations of the Italian corporate financial market (Lamandini 2001; Abriani 2002; Tombari 2002; Bianchi and Giannelli 2003). Traditionally, the Code provided for only two forms of securities for the public company model (hereinafter, SPA), namely, shares and bonds. The 2003 reform led to an increased blurring of the traditional differences between the two kinds of securities admitted for SPA by allowing corporations to freely modify them in accordance with some limited principles and by introducing new financial hybrid instruments.

These kinds of securities are covered by a limited regulation in art. 2346, 6th co., civil code (hereinafter, c.c.), which allows the issuers to link the debt more strictly to corporate affairs. Indeed, the owners of such securities may participate in the corporations' affairs in two different ways. The first and most common way consists of exposing the value of securities to entrepreneurial risk either partially or wholly as shareholders do. The second way consists of the possibility of creditors taking part indirectly in the management, having the right to vote on some predetermined issues (for a similarity with voting bonds, see Enriques 2005a; Cian 2005; Notari and Giannelli 2008) or nominating an independent director (art. 2351, 5th co., c.c.). The freedom to differently match these characteristics enables issuers to create debt securities not directly exposed to the company's trend like normal bonds but with 
the right to designate a qualified member of the board or to vote on predetermined arguments, such as a right of veto regarding new financial operations or similar covenants giving the holders the right to approve the managers' decisions (Pisani Massamormile 2003; Perugino 2004; Mignone 2004; Cian 2005; Campobasso 2006; Ferrara and Corsi 2006; Notari and Giannelli 2008).

The 2003 reform did not deeply modify art. 2410-2420-ter c.c., which regulates the issues of non-participating bonds and the assembly of underwriters. The most relevant amendments concerned the removal of the issuing limit rule for listed SPAs (calculated by the sum of the legal capital and the reserves owned by the issuer) in favour of market monitoring of the companies' sustainable indebtedness (Brescia Morra 2003; Palmieri 2006a), which seems to partially sustain the criticism over legal capital rules recently voiced by some authors (for the Italian debate, see: Enriques and Macey 2002; Denozza 2002; Enriques 2005b). On the contrary, the reform did not change the part of the Italian Civil Code that regulates the assembly of bondholders. The primary duties of the assembly continue to be the approval of debt renegotiation proposals and the election of a delegate, the only direct counterpart of the SPA on questions concerning the debt contract. ${ }^{3}$ However, because of the debtors' indifference, the delegate is normally chosen by a court at the request of the management of the SPA itself. In any case, the bondholders' representative lacks adequate power to check the issuer's moves, as he has only the right to attend the shareholders' meeting, read the minutes of debates, and look into the shareholders' register, whereas he is denied direct access to the most important account books. These limitations reduce the delegate's capacity to perceive the company's financial distress and, consequently, to propose preventive debt renegotiation, which should be approved by the majority of bondholders. This organisational formula seems to work only for bonds and for companies' trendrelated hybrid securities on the strength of art. 2411, 3rd comma, c.c. On the contrary, art. 2376 c.c. provides only that the owners of administrative participating hybrids, if not those of the company's trend-related hybrids, should meet in an assembly to vote on the proposal to modify their administrative rights in compliance with the rules governing the extraordinary meeting of shareholders, without having the explicit right to nominate a delegate as bondholders do (Corsi 2003; Pisani Massamormile 2003; Mignone 2004; Stagno d'Alcontres 2004; Sarale 2004; Ferrara and Corsi 2006; contra Ferri 2003; Tombari 2006; Campobasso 2006, who extend the applicability of the representative structure provided for bondholders).

Both of the described legal models seem to lack efficacy in preventing a borrower's default, mainly because the assembly's vote requires a long interval of time, which normally becomes a determinant for the approval of a debt renegotiation plan following an unexpected financial crisis (Palmieri 2006b). Furthermore, art. 2376 c.c. presents considerable problems in unifying the will of the bondholders, who are often represented as dispersed money savers without an adequate financial culture, due to the lack of a delegate that could act as an active sentinel for them and, at the same time, as a unique contractual counterpart for the

\footnotetext{
${ }^{3}$ Although this task could be assigned to a single person, a financial service company or a trust company are also considered eligible.
} 
company's board of directors. Nonetheless, the short text of art. 2376 c.c. permits contractual improvement of the legal discipline by providing a kind of representative mechanism similar to the "supertrustee" for the management of the economic terms of the debt, which are not regulated by the law.

\section{A proposal for the Italian corporate bonds market}

The Trust Indenture Act of 1939 (codified at 15 U.S. Code $\S 77$ aaa through $\S 77 \mathrm{bbbb})$ prohibits the offering of bond issues for sale without a formal written agreement (i.e., an indenture) that fully lays out the details of the bond issue. The Act also stipulates that a trustee must be appointed for the protection of the bond investors. In the event that a bond issuer should become insolvent, the appointed trustee may be given the right to seize the issuer's assets and sell them to recoup the bondholders' investments. The main difference between the Italian bondholders' delegate and the trustee provided by the Trust Indenture Act is the extension of the powers of the latter, who must exercise them in cases of default with the "same degree of care and skill ... as a prudent man" would use for his own affairs ( $\$$ 77ooo(c)). However, the operational freedom (criticised by Schwarcz and Sergi 2008 , for being too ministerial in the pre-default phase and too weak in the postdefault phase, as it is not aimed at maximising the bondholders' value return) is covered by $\S 77 \mathrm{ppp}(\mathrm{a})(1)$, which authorises the majority of bondholders to "direct the time, method, and place of conducting any proceeding for any remedy available to such trustee, or exercising any trust or power conferred upon such trustee" and "on behalf of the holders of all such indenture securities, to consent to the waiver of any past default and its consequences". Furthermore, the bondholders of not less than three fourths of the indenture securities amount may consent, on behalf of all the holders, to postpone the payment of interests for a period not exceeding 3 years from the due date $(\S 77 \mathrm{ppp}(\mathrm{a})(2)$; a similar provision is contained in Sect. 750(2)(b)(i) of the English Companies Act of 2006).

The "supertrustee" proposal elaborated by Amihud et al. (2000) aims to improve the tasks and duties of the trustee in the pre-default phase on the strength of an agreement, including the power to act independently of the bondholders according to a business judgement standard (Schmidt 2006, and Schwarcz and Sergi 2008, also embrace this solution). From a market-based perspective, the adoption of a "supertrustee" should be voluntary, devolving the choice on the issuer. The company should consider the balance of the burden to finance such a counterpart and the benefits of a reduction in borrowing costs achieved by the use of tighter bond covenants as resulting from a more efficient relationship with dispersed debt holders. This legal scheme could probably also be borrowed by the Italian corporate dispersed debt market. ${ }^{4}$

\footnotetext{
${ }^{4}$ However, the use of the trust model is still exceptional in Italy: in obedience to the Civil Law tradition, the Italian lawmaker does not generally support a legal distinction between legal ownership and equitable ownership. On the contrary, the regulation concerning financial services traditionally contains provisions about a securities indenture in favour of a beneficiary: Law. no. 1966 of 1939 provided for the "società fiduciaria" (trust company) to supply real assets or securities portfolio fiduciary managements.
} 
As explained in the previous paragraph, the Italian Civil Code seems to provide two different models of representation for dispersed debt creditors of SPAs: the bondholders' assembly, on the one hand, and the delegate model for bonds and for a company's trend-related debt securities, on the other. In contrast, only the special assembly method is admitted for hybrids that confer administrative rights. From the debtors' perspective, the latter appear to be the most interesting type of securities introduced in the 2003 reform, as they provide opportunity to insert a "sentinel" within the core of the company (Vella 2004). In any case, the lack of a representative figure is a strong obstacle to the success of a hypothetical renegotiation, both in a pre-default phase and in case of a covenant breach. This legal deadlock can be partially broken by contractually implementing the narrow discipline contained in art. 2376 c.c. and by introducing the opportunity to let the financial market counterparts negotiate an alternative model of creditors' representation (Pisani Massamormile 2003) similar to the "supertrustee" proposed by Amihud et al. (2000). This solution can simply be achieved by inserting into the debt contract the mandatory representation of an investment firm that exercises the custodianship and administration of financial instruments for the accounts of clients (as allowed by legislative decree no. 58 of 1998, art. 199, art. 1, co. 6 (a); see also art. 1838 c.c.: Perassi 2001), which can be implemented by the insertion of an appropriate clause in the prospectus (see provision no. 4.13 of Annex V of EC Regulation no. 809/2004). The bank or investment firm organising the initial public offering of debt securities as lead manager may directly promote this form of representation by electing an affiliated or third-party investment firm as the sole delegate of the holders of the securities, mandated to exercise full power according to a business judgement standard with the express consent of the underwriters required by legislative decree no. 58 of 1998, art. 21, co. 2 .

The operational freedom of the delegate should include the power to sign debt renovation agreements and transactions about the financial terms of the debt, including most parts of the possible covenants, excepting the modification of active administrative rights in compliance with art. 2376 c.c. Nonetheless, this service should not represent a kind of portfolio management because it would not be a service on a "client-to-client basis"; rather, it would be a mass-debt administration similar to that exercised by the bondholders' delegate although including extraordinary management tasks. The prospectus could also recognise the debtors' right to veto the core terms of the renegotiation proposal, which Amihud et al. (2000) propose as a secondary, sub-optimal choice (contra Bratton 2006, who prefers only the ratification of payment terms recontracting, with the exclusion of covenant amendments so as not to expose the debtor to the uncertainty of the lenders' vote).

Footnote 4 continued

Nevertheless, after the Investment Services Directive of 1993 was acknowledged by legislative decree no. 415 of 1996, the "società fiduciarie" may continue to exercise single-portfolio management as trust companies, but they cannot more directly operate other financial services on behalf of their clients in respect of the rule of separation of assets (art. 60, actually applicable by legislative decree no. 58 of 1998, art. 199; Costi 2008). 
This proposal will reduce the costs incurred in the event of violations of the covenant $c_{B}(c o)$. The necessary conditions for the firm will become wider as the difference (12) becomes larger. Thus, the firm will issue the bond with a lower value of $d$, and the probability of the firm choosing a standard bond instead of a bond with a covenant will become lower. The proposal will also reduce the cost of monitoring $m_{B}(\mathrm{co})$ so that the costs of administration, which are quite irrelevant during the ordinary phase (mainly the independent director's fee), could be sustained by the debt holders. This cost does not change the necessary condition because expression (12) is independent of the value of the monitoring costs. The cost of monitoring can also be sustained by the issuer or by the investment firm as an incentive for the issue. In the event of a breach of the covenant or in case of a payment default, the renegotiation costs (for example, the cost of extra monitoring or, if necessary, the cost of the bondholders' assembly) should be paid by the issuer (or the investment firm partially charged with the costs) to defend the creditors' value maximisation principle and to avoid stimulating opportunistic behaviour among debtors. In this case, however, the choice set for the firm $\Omega_{F}$ will become restricted because the total violation $\operatorname{costs} c_{F}$ for the firm will increase. Thus, this possibility should be used only in the case of complex covenants ${ }^{5}$ as underlined in the "supertrustee" model in which compensation "should be greater for bonds with more complex covenants, for bonds issued by companies with more complicated and less transparent operating characteristics, and for bonds bearing more credit risk and for which more intense monitoring is appropriate and more renegotiation is likely to be needed" (Amihud et al. 2000).

The problem of a possible conflict of interest between the bondholders and the lead investment manager or the affiliated firm could be solved by giving creditors the opportunity to change the delegate by majority vote required by art. 2376 c.c. and to choose another firm to supply the same service. As the authors of the "supertrustee" model suggest, a debt contract should provide a list of candidates submitted by the borrower to reduce the danger of dealing with an opportunistic representative firm designated by the bondholders. Moreover, the risk of ruining their reputation with clients or of becoming defendants in an injunctive class action suit (a tool recently introduced into the Italian financial market as well) can be considered sufficient incentives to get the investment firm to effectively fulfil its representative duties.

\section{Conclusions}

Bond covenants can be an effective tool in reducing the conflicts of interest between shareholders and bondholders. Lack of coordination between bondholders, however, may reduce the efficiency of such instruments due to the high expected costs of

\footnotetext{
5 The costs in the case of a covenant violation normally increase with the complexity of the covenant's structure. At a low level of complexity, they could assigned to the bondholders, but with increased complexity, they become greater for the bondholders than for the firm (or for the investment firm), mainly because of the different levels of information and the disparity of financial knowledge. Thus, in this case, to reduce the costs, costs should be assigned to the firm.
} 
renegotiation following covenant violations. In fact, the empirical evidence shows that in the case of bank loans, where coordination is high, the violation costs are lower and the use of covenants is more efficient. With the help of a formalised example for the bond issue, it is possible to identify the cost of the lack of coordination between bondholders. It is easy to verify the efficiency of the use of covenants if the bondholders decide to create a "supertrustee". This possibility was suggested for the U.S. market by Amihud et al. (2000) and, more recently, by Bratton (2006). Following this indication, even if not directly applicable, we propose an application in Italian law allowing the insertion of a mandatory representation into the new financial hybrid contracts. The representation, an alternative to the model provided by the Italian Civil Code, would give an investment firm exercising the administration of financial instruments the right to act with full power on behalf of all of the holders of the securities.

The analysis can be furthered by identifying the costs of the procedure and the minimal dimensions that the bond should satisfy, adding these hypotheses to the formalised example to show how the results can change.

Acknowledgments We would like to thank Paola De Vincentiis, Yunbi An, an anonymous referee, and seminar participants at the second annual conference of Italian Association of Scholars of Economics and Management of Financial Institutions and Markets (ADEIMF), Capri (Italy), June 13-14, 2008, and at the European Financial Management Association Annual Meeting (EFMA), Milan (Italy), June 24-27, 2009, for comments that were helpful in developing this work. All errors are the authors' alone.

\section{References}

Abriani, N. (2002). La struttura finanziaria delle società di capitali nella prospettiva della riforma. Rivista del diritto commerciale e del diritto generale delle obbligazioni, 100(1), 131-154.

Abriani, N. (2004). Dal caso Parmalat alle nuove regole a tutela del risparmio. Le società, 23(3), 269-271.

Amihud, Y., Garbade, K., \& Kahan, M. (2000). An institutional innovation to reduce the agency costs of public corporate bonds. Journal of Applied Corporate Finance, 13(1), 114-121.

Asquith, P., Weber, J., \& Beatty, A. (2005). Performance pricing in bank debt contracts. Journal of Accounting and Economics, 40(1-3), 101-128.

Banfi, A., \& Di Pasquale, F. (2003). Titoli di debito e riforma del diritto societario: Alcune valutazioni critiche. Analisi giuridica dell'economia, 2(2), 407-419.

Beatty, A., \& Weber, J. (2003). The effects of debt contracting on voluntary accounting method changes. The Accounting Review, 78(1), 119-142.

Beatty, A., Ramesh, K., \& Weber, J. (2002). The importance of accounting changes in debt contracts: The cost of flexibility in covenant calculations. Journal of Accounting and Economics, 33(2), 205-227.

Beneish, M. D., \& Press, E. (1993). Costs of technical violation of accounting-based debt covenants. The Accounting Review, 68(2), 233-257.

Bertinetti, G. (2000). L'esame del caso italiano. In A. Bertoni (Ed.), La finanza per lo sviluppo del sistema industriale italiano. Milano: EGEA.

Bianchi, L. A., \& Giannelli, A. (2003). Riforma del diritto societario e corporate bond. In C. M. Pinardi (Ed.), Il mercato dei corporate bond in Italia. Milano: Egea.

Billet, M. T., Dolly King, T., \& Mauer, D. C. (2007). Growth opportunity and the choice of leverage, debt maturity, and covenants. The Journal of Finance, 62(2), 697-730.

Black, E. L., Carnes, T. A., Mosebach, M., \& Moyer, S. E. (2004). Regulatory monitoring as a substitute for debt covenants. Journal of Accounting and Economics, 37(3), 367-391.

Bolton, P., \& Scharfstein, D. S. (1996). Optimal debt structure and the number of creditors. The Journal of Political Economy, 104(1), 1-25. 
Bradley, M., \& Roberts, M. R. (2004). The structure and pricing of corporate debt covenants. http://ssrn.com/abstract=585882.

Bratton, W. W. (2006). Bond covenant and creditor protection: economics and law, theory and practice, substance and process. European Business Organization Law Review, 7(1), 39-87.

Brescia Morra, C. (2003). Finanziamento delle società di capitali e titoli di debito. www.dircomm.it, 2(11).

Bris, A., \& Welch, I. (2005). The optimal concentration of creditors. The Journal of Finance, 60(5), 2193-2212.

Cafaggi, F. (2002). Complementarietà istituzionali ed evoluzione dei modelli organizzativi nella riforma del diritto societario. Mercato concorrenza regole, 1(4), 9-44.

Camerer, C., \& Knez, M. (1996). Coordination, organizational boundaries and fads in business practices. Industrial and Corporate Change, 5(1), 89-112.

Campobasso, G. F. (2006). Diritto commerciale. Torino: Utet.

Canovi, L., Grasso, A., \& Venturelli, V. (2007). Il fabbisogno di capitale di rischio delle PMI innovative in Italia. Banca impresa società, 26(2), 309-334.

Carletti, E. (2004). The structure of bank relationships, endogenous monitoring, and loan rates. Journal of Financial Intermediation, 13(1), 58-86.

Chava, S., \& Roberts, M. (2008). How does financing impact investment? The role of debt covenants. The Journal of Finance, 63(5), 2085-2121.

Chava, S., Kumar, P., \& Warga, A. (2005). Agency costs and the pricing of bond covenants. Working paper. Houston: University of Houston.

Cian, M. (2005). Gli strumenti finanziari di s.p.a.: pluralità delle fattispecie e coordinamento delle discipline. Giurisprudenza commerciale, 32(3), 382-406.

Corigliano, R. (2007). Banca e impresa in Italia: caratteri evolutivi del relationship lending e sostegno dello sviluppo. Banca impresa società, 26(1), 27-58.

Corsi, F. (2003). La nuova s.p.a.: gli strumenti finanziari. Giurisprudenza commerciale, 30(4), 414-421.

Costi, R. (2008). Il mercato mobiliare. Torino: Giappichelli.

Cotter, J. (1998). Utilisation and restrictiveness of covenants in Australian private debt contracts. Accounting and Finance, 38(2), 181-196.

Damodaran, A. (2001). Corporate finance: Theory and practice. New Jork: Wiley.

Demiroglu, C., \& James, C. (2010). The information content of bank loan covenants. The Review of Financial Studies, 23(11), 3700-3737.

Denozza, F. (2002). A che serve il capitale (piccole glosse a L. Enriques-J.R. Macey, creditors versus capital formation: The case against the european legal capital rules). Giurisprudenza commerciale, 29(5), 585-600.

Detragiache, E., Garella, P., \& Guiso, L. (2000). Multiple versus single banking relationships: Theory and evidence. The Journal of Finance, 55(3), 1131-1161.

Di Staso, M. K. (2004). Il caso Parmalat. Archivio CERADI, Agosto, 1-69.

Dimundo, F. (2003). Art. 2346 c.c. In G. Lo Cascio (Ed.), La riforma del diritto societario. Milano: Giuffrè.

Eidenmüller, H., Engert, A., \& Hornuf, L. (2010). Where do firms issue debt? An empirical analysis of issuer location and regulatory competition in Europe. ECGI Finance Working Paper, 292.

Enriques, L. (2005a). Quartum non datur, appunti in tema di «strumenti finanziari partecipativi» in Inghilterra, negli Stati Uniti e in Italia. Banca, borsa. titoli di credito, 58(2), 166-183.

Enriques, L. (2005b). Capitale sociale, informazione contabile e sistema del netto: una risposta a Francesco Denozza. Giurisprudenza commerciale, 32(5), 607-629.

Enriques, L., \& Macey, J. R. (2002). Raccolta del capitale di rischio e tutela dei creditori: una critica radicale alle regole europee sul capitale sociale. Rivista delle società, 47(1), 78-120.

Ferrara, F., \& Corsi, F. (2006). Gli imprenditori e le società. Milano: Giuffrè.

Ferri, G. (2003). Fattispecie societaria e strumenti finanziari. Rivista del diritto commerciale e del diritto generale delle obbligazioni, 101(4), 805-828.

Fimmanò, F. (2004). I gap di informazione e controllo nei crac Cirio e Parmalat e le prospettive di riforma. Le società, 23(4), 401-413.

Fortunato, S. (2004). I «fallimenti» nel sistema dei controlli sui mercati finanziari (a margine del d.d.l. sulla tutela del risparmio). Rivista delle società, 23(8), 929-937.

Garleanu, N., \& Zwiebel, J. (2009). Design and renegotiation of debt covenants. Review of Financial Studies, 22(2), 749-781. 
Hubert, F., \& Schäfer, D. (2002). Coordination failure with multiple-source lending, the cost of protection against a powerful lender. Journal of Institutional and Theoretical Economics, 158(2), 256-275.

Inzitari, B. (2005). L'inadeguata tutela civile del risparmio. In E. Paciotti \& G. Salvi (Eds.), Enron e Parmalat. Due "sistemi-paese" a confronto. San Cesario di Lecce: Manni.

Jensen, M. C., \& Meckling, W. H. (1976). Theory of the firm: Managerial behaviour, agency costs and ownership structure. Journal of Financial Economics, 3(4), 305-360.

Kwan, S. H., \& Carleton, W. T. (2010). Financial contracting and the choice between private placement and publicly offered bonds. Journal of Money Credit and Banking, 42(5), 907-929.

Lamandini, M. (2001). Struttura finanziaria e governo delle società. Bologna: Il Mulino.

Lamandini, M. (2003). Autonomia negoziale e vincoli di sistema nella emissione di strumenti finanziari da parte delle società per azioni e delle cooperative per azioni. Banca borsa titoli di credito, 56(5), $519-541$.

Lolli, A. (2005). Gli strumenti finanziari. In A. Maffei Alberti (Ed.), Il nuovo diritto delle società. Padova: Cedam.

Mather, P. R. (1999). Financial covenants in Australian private debt contracts: Incidence, measurement rules and monitoring. Australian Accounting Review, 9(17), 63-72.

Mather, P., \& Peirson, G. (2006). Financial covenants in the markets for public and private debt. Accounting and Finance, 46(2), 285-307.

Mignone, G. (2004). Art. 2346, $6^{\circ}$ comma. In G. Cottino, G. Bonfante, O. Cagnasso, \& P. Montalenti (Eds.), Il nuovo diritto societario. Bologna: Zanichelli.

Morris, S., \& Shin, H. S. (2004). Coordination risk and the price of debt. European Economic Review, 48(1), 133-153.

Myers, S. C. (1977). Determinants of corporate borrowing. Journal of Financial Economics, 5(2), 147-175.

Nash, R., Netter, J. M., \& Poulsen, A. B. (2003). Determinants of contractual relations between shareholders and bondholders: investment opportunities and restrictive covenants. Journal of Corporate Finance, 9(2), 201-232.

Nigro, A. (2005). La tutela del risparmio e l'efficienza del sistema: Il ruolo delle banche. Le società, 14(3), 315-328.

Niskanen, J., \& Niskanen, M. (2004). Covenants and small business lending: The Finnish case. Small Business Economics, 23(2), 137-149.

Notari, M. (2003). Azioni e strumenti finanziari: confini delle fattispecie e profili di disciplina. Banca borsa titoli di credito, 56(5), 542-558.

Notari, M., \& Giannelli, A. (2008). Art. 2346, comma 6. In P. G. Marchetti, L. A. Bianchi, F. M. Ghezzi, \& M. Notari (Eds.), Commentario alla riforma delle società. Milano: Giuffrè-Egea.

Onado, M. (2003). I risparmiatori e la Cirio: ovvero, pelati alla meta. Storie di ordinaria spoliazione di azionisti e obbligazionisti. Mercato concorrenza regole, 8(3), 499-536.

Ongena, S., \& Smith, D. (2000). What determines the number of bank relationships? Cross country evidence. Journal of Financial Intermediation, 9(1), 26-56.

Paglia, J. K., \& Mullineaux, D. J. (2006). An empirical exploration of financial covenants in large bank loans. Banks and Bank Systems, 1(2), 103-122.

Pagnoni, E. (2005). Negoziazione e collocamento «riservato» come modelli alternativi di offerta dei prodotti finanziari. Le società, 24(2), 157-161.

Palmieri, M. (2006a). I nuovi limiti all'emissione di obbligazioni. Giurisprudenza commerciale, 33(2), 293-319.

Palmieri, M. (2006b). I bond covenants. Banca Impresa Società, 25(2), 247-279.

Pardolesi, R. A., \& Portolano, M. P. A. (2004). Latte, lacrime (da coccodrillo) e sangue (dei risparmiatori). Note minime sul caso Parmalat. Mercato concorrenza regole, 5(1), 195-215.

Perassi, M. (2001). Il deposito titoli in amministrazione. In G. Cottino (Ed.), Trattato di diritto commerciale. Padova: Cedam.

Perugino, S. (2004). Gli strumenti finanziari alla luce della riforma del diritto societario. Le società, 8 , 941-948.

Pisani Massamormile, A. (2003). Azioni ed altri strumenti finanziari partecipativi. Rivista delle società, $48(6), 1268-1315$.

Qi, Y., \& Wald, J. K. (2008). State laws and debt covenants. The Journal of Law and Economics, 51(1), 179-207.

Rajan, R. G. (1992). Insiders and outsiders: The choice between informed and arm's length debt. The Journal of Finance, 47(4), 1367-1400. 
Sarale, M. (2004). Commento sub art. 2411. In G. Cottino, G. Bonfante, O. Cagnasso, \& P. Montalenti (Eds.), Il nuovo diritto societario. Bologna: Zanichelli.

Schmidt, K. M. (2006). The economics of covenants as a means of efficient creditor protection. European Business Organization Law Review, 7(1), 89-94.

Schwarcz, S., \& Sergi, G. M. (2008). Bond Defaults and the Dilemma of the Indenture Trustee. Alabama Law Review, forthcoming.

Smith, C. W. (1993). A perspective on accounting-based debt covenant violations. The Accounting Review, 68(2), 289-303.

Smith, C., \& Warner, J. (1979). On financial contracting: An analysis of bond covenants. Journal of Financial Economics, 7, 117-161.

Stagno d'Alcontres, A. (2004). Art. 2376. In G. Niccolini \& A. Stagno d'Alcontres (Eds.), Società di capitali. Napoli: Jovene.

Stanca, L. (2003). Imprese italiane e ricorso al mercato del debito: I corporate bond. In C. M. Pinardi (Ed.), Il mercato dei corporate bond in Italia. Milano: EGEA.

Sweeney, A. P. (1994). Debt-covenant violations and managers' accounting responses. Journal of Accounting and Economics, 17(3), 281-308.

Takeda, K. (2003). The influence of large creditors on creditor coordination. Economics Bulletin, 7, 1-11.

Takeda, F., \& Takeda, K. (2008). How large creditors affect corporate bond prices through creditor coordination. Journal of International Economic Studies, 22, 31-49.

Tombari, U. (2002). Azioni di risparmio e tutela dell'investitore (verso nuove forme rappresentative della società con azioni quotate). Rivista delle società, 47(5), 1062-1117.

Tombari, U. (2006). Gli strumenti finanziari nella riforma delle società di capitali. Rivista delle società, 52(1), 143-161.

Unicredit Banca Mediocredito, \& Centrale dei Bilanci. (2005). I covenant di bilancio nei finanziamenti a medio e lungo termine. Rome: Bancaria Editrice.

Vella, F. (2002). Diritto societario e modelli di sviluppo delle PMI. In Associazione. Disiano. Preite (Ed.), Verso un nuovo diritto societario. Bologna: Il Mulino.

Vella, F. (2004). Nuove regole di corporate governance e tutela degli investitori. Banca Impresa Societa, 23(3), 464-470.

Zara, C., \& Feltrinelli, E. (2006). PMI, rapporti con i finanziatori e complessità di impresa. Banca impresa società, 25(2), 281-310. 